\title{
Livestock response to multispecies and deferred-rotation grazing on forested rangeland
}

\author{
KENNETH C. OLSON, RANDALL D. WIEDMEIER, JAMES E. BOWNS, AND REX L. HURST
}

Authors are associate professors, Animal, Dairy, and Veterinary Sciences Dept., professor, Rangeland Resources Dept., and professor emeritus, Agricultural Experiment Station, Utah State University, Logan, Ut. 84322-4815.

\begin{abstract}
Performance of cow-calf (Bos taurus) and ewe-lamb (Ovis aries) units was compared under multispecies versus singlespecies grazing and deferred-rotation versus continuous stocking during a 10-year grazing trial. Treatments were arranged in a 3 species (cattle, sheep, or both species) by 2 grazing method (deferred rotation or continuous) factorial using a randomized-complete block design with 2 blocks. All animals were individually weighed at initiation, mid-point, and termination of each grazing season. Livestock species and grazing method did not interact for any dependent variable $(P>0.05)$. Average daily gain $($ ADG) was greater $(P<0.05)$ when calves were alone than when mixed with sheep (1.04 vs $1.01 \mathrm{~kg} \mathrm{day}^{-1}$, respectively), but ADG of lambs was greater $(P<0.05)$ when mixed with cattle than alone $(0.25 \mathrm{vs} 0.23 \mathrm{~kg}$ day $^{-1}$, respectively). Cow and ewe ADG were unaffected $(\mathbf{P}>\mathbf{0 . 0 5})$ by animal species mixture. Production of progeny (gain of calves and lambs) and total production (gain of progeny and dams) per ha was greater $(P<0.05)$ using sheep or mixed species than cattle $\left(17.8,17.8\right.$, and $11.2 \mathrm{~kg} \mathrm{ha}^{-1}$ respectively, for progeny, and $22.4,24.5$, and $17.6 \mathrm{~kg} \mathrm{ha}^{-1}$ respectively, for total). Calves grew faster $(\mathbf{P}<\mathbf{0 . 0 5})$ under continuous than deferred-rotation grazing $\left(1.04 \mathrm{vs} 1.01 \mathrm{~kg} \mathrm{day}^{-1}\right)$. Ewes gained more rapidly $(\mathbf{P}<0.05)$ during the second half of the grazing season under deferred-rotation than continuous grazing $\left(0.049\right.$ vs $\left.0.023 \mathrm{~kg} \mathrm{day}^{-1}\right)$. Multispecies or sheep grazing appeared more appropriate than cattle for this environment. Deferred-rotation grazing appeared superior for sheep performance, but continuous grazing allowed greater calf performance.
\end{abstract}

Key Words: common grazing, mixed species grazing, dual grazing, livestock performance, grazing systems, grazing methods

Concurrent grazing with more than 1 species of animal is expected to improve animal performance, carrying capacity, and range condition and productivity (Nolan and Connolly

This research was supported by the Utah Agricultural Experiment Station, Utah State University, Logan, UT 84322-4810. Approved as Journal Paper No. 6005.

The authors acknowledge the contributions of former principal investigator involved throughout the life of this project who allowed such long-term research to be possible, including Darrell Matthews, Warren Foote, and Gary Snowder.

Manuscript accepted 11 Nov. 1998.
Resumen

En un ensayo de 10 años de duración, se comparó el comportamiento de unidades de vaca-becerro (Bos taurus) y oveja-cordero (Ovis aries) apacentando en forma combinada e individual en los sistemas de apacentamiento de rotacional diferido y continuo. Los tratamientos se evaluaron bajo un diseño experimental de bloques completos al azar en arreglo factorial de 3 especies (bovinos, ovinos o ambas especies) y 2 métodos de apacentamiento (rotacional diferido y continuo). Todos los animales se pesaron individualmente al inicio, mediados y fin de cada estación de apacentamiento. La especie de ganado y el método de apacentamiento no interactuaron con ninguna de las variables dependientes $(P>0.05)$. La ganancia diaria promedio de peso (GDP) fue mayor $(\mathbf{P}<\mathbf{0 . 0 5})$ cuando los becerros apacentaron solos que mezclados con borregos (1.04 vs $1.01 \mathrm{~kg} \mathrm{day}^{-1}$ ), en contraste la GDP de los corderos fue mayor $(\mathbf{P}<\mathbf{0 . 0 5})$ cuando apacentaron mezclados con bovinos que cuando lo hicieron solos $(0.25$ vs 0.23 $\left.\mathrm{kg} \mathrm{day}^{-1}\right)$. La GDP de vacas y ovejas no fue afectada $(\mathbf{P}>0.05)$ por la mezcla de especies animal. La producción de la progenie (ganancia de becerros y corderos) y la producción total (ganancia de la progenie y madres) por hectárea fue mayor (P < 0.05) utilizando ovinos o especies combinadas que apacentando solo bovinos $\left(17.8,17.8\right.$ y $11.2 \mathrm{~kg} \mathrm{ha}^{-1}$ respectivamente para la progenie y $22.4,24.5$ y $17.6 \mathrm{~kg} \mathrm{ha}^{-1}$ para la producción total). Los becerros crecieron más rápido $(P<0.05)$ en el sistema de apacentamiento continuo que en el rotacional diferido (1.04 vs $1.01 \mathrm{~kg} \mathrm{day}^{-1}$ ). Durante la segunda mitad de la estación de apacentamiento, las ovejas ganaron peso más rápidamente $(\mathbf{P}<0.05)$ en el sistema rotacional diferido que en el continuo ( 0.049 vs $\left.0.023 \mathrm{~kg} \mathrm{day}^{-1}\right)$. Para este ambiente, el uso de ovinos o especies combinadas parece ser más apropiado que el uso de bovinos. El sistema rotacional diferido parece ser superior para el comportamiento de ovinos; sin embrago, el apacentamiento continuo permitió un mejor comportamiento productivo de los becerros.

1997, Walker 1994, 1997). These benefits are expected to be greatest on diverse landscapes, such as rangelands, where animal specific differences in diet selection and grazing distribution can be exploited to obtain more uniform utilization of the entire resource (Baker and Byington 1986). Most grazing trials to evaluate livestock responses to multispecies grazing have been done on improved pastures (e.g. Bennett et al. 
1970, Nolan and Connolly 1989, Abaye et al. 1994), with the only U.S. rangeland studies conducted in Texas (Merrill and Young 1954, Merrill et al. 1966, Taylor 1985).

Grazing experiments to evaluate livestock responses to deferred-rotation have been more common. Literature reviews of animal responses to grazing methods (e.g. Driscoll 1967, Pieper 1980) indicated that specialized grazing methods, including deferred-rotation and others, have decreased or had no effect on animal performance in the majority of studies, with relatively few instances of a specialized grazing method improving animal performance.

A study was conducted from 1980 through 1990 to evaluate performance of sheep and cattle when grazed together or separate under continuous stocking or deferred-rotation grazing on high-elevation summer range. Matthews et al. (1986) published livestock data from early years of this study. Results concerning a second objective to evaluate vegetation responses will be published separately.

\section{Materials and Methods}

\section{Study Site}

The study was conducted at a Utah Agricultural Experiment Station (UAES) research site located about 43 $\mathrm{km}$ southeast of Cedar City, Ut. (about $37^{\circ} 30^{\prime}$ North latitude, $113^{\circ}$ West longitude). The site consisted of about 1,310 ha of privately owned rangeland leased by UAES. The mean elevation of the site was about $2,600 \mathrm{~m}$, and ranged from 2,300 to $2,900 \mathrm{~m}$. The site had a typical montane physiography. The vegetation was a mosaic of forested and open plant communities. The overstory of the forested areas was quaking aspen (Populus tremuloides Michx.) or Gambel's oak (Quercus gambelii Nutt.). The herbaceous vegetation was dominated by grasses, primarily Letterman's needlegrass [Achnatherum lettermanii (Vasey) Barkworth], Kentucky bluegrass (Poa pratensis L.), slender wheatgrass [Elymus trachycaulus ssp. trachycaulus (Link) Gould ex Shinners], and mountain brome (Bromus marginatus Nees ex Steud.). The most common forbs were American vetch (Vicia americana Muhl. ex Willd.) and mountain tarweed (Madia glomerata Hook.). The

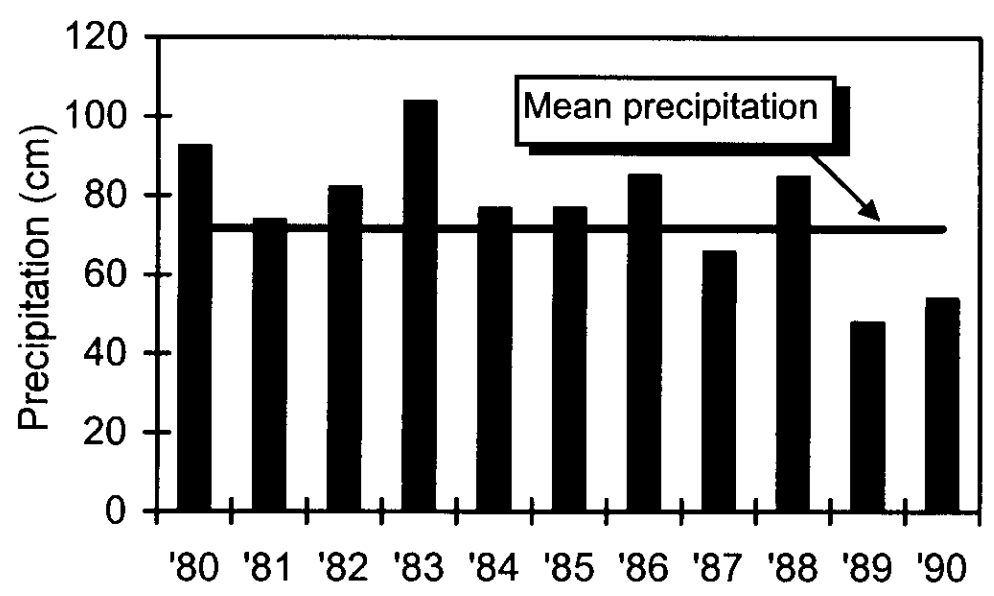

Fig. 1. Annual precipitation during each year of the study period and long-term mean precipitation (1970-1992).

most prevalent shrub was mountain snowberry (Symphoricarpos oreophilus var. oreophilus Gray). Bowns and Bagley (1986) indicated potential natural vegetation for this area should be dominated by tall forbs, but historical, heavy sheep grazing has caused the shift to grass dominance.

Precipitation records have been maintained from 1970 to present at a similar elevation about $10 \mathrm{~km}$ north of the study site (Fig. 1). The precipitation pattern is bimodal, with peaks during winter as snow and late summer as thunderstorms. Precipitation was above average during the first 7 years of the study, but below average during 3 of the final years. This allowed the opportunity to observe responses during good and poor growing conditions.

\section{Grazing Treatments}

Mixed species grazing (cattle alone, or cattle-sheep mixed) and grazing method (season-long or deferred-rotation) were replicated twice in a randomized-complete block design using a $3 \times 2$ factorial arrangement. For mixed-species grazing, 5 ewes with progeny were substituted for 1 cow-calf pair, which is the most commonly accepted replacement ratio, and is based on relative differences in forage consumption (Walker 1994). Deferred-rotation grazing used 2 paddocks, with rotation at about the middle of the grazing season. The paddock grazed initially was alternated in consecutive years. Considering that deferred-rotation required 2 paddocks per experimental unit, the study site was fenced into 18 individual paddocks of about 73 ha each. Paddock size ranged from 57 to 87 ha. Thus, each experimental unit of deferred-rotation was about twice the size of each experimental unit of continuous stocking, but the area occupied by livestock at any point in time was similar. One pond was excavated in each paddock to provide livestock water. The blocking factor was visual similarity of paddocks based on physiographic and vegetative characteristics described above. Paddocks were assigned randomly to treatment within block except 1 paddock containing tall larkspur [Delphinium barbeyi (Huth) Huth] was purposefully assigned sheep only to avoid poisoning cattle.

Stocking rate was set in the initial year based on historical stocking rates on the study site and was subsequently adjusted annually at the beginning of the grazing season in each experimental unit based on previous year's utilization and amount of winter precipitation received before initiation of grazing. Utilization was visually estimated at the end of each grazing season based on relative uniformity of remaining herbage among experimental units. Thus, stocking rate was adjusted in each experimental unit based on differences in previous year use and expected forage abundance to achieve targeted use of about 50 to $55 \%$.

Cooperating producers provided livestock. The same cow herd was used throughout the study. Cattle breeds included Herefords and crosses of other breeds, primarily Angus and Simmental, on Herefords. Calves were born in February and March throughout the study, and weaned after the livestock 
were removed from the study site each year. The sheep used from 1980 through 1984 were from the Utah State University (USU) research flock located at Southern Utah University in Cedar City. This flock was sold in 1984. Sheep were provided in remaining years by a local producer that bought a large portion of the USU flock, allowing many of the same sheep to remain in their treatments through this transition. Sheep breeds in both flocks were straightbreds or crosses of Targhee, Suffolk, Rambouillet, and Finn. Lambs were born in April and were weaned in midSeptember throughout the study. Individual cows and ewes were permanently assigned to treatment groups so they returned to the same experimental unit each year. Cows and ewes were stratified to treatment groups at initiation of the experiment by breed and age. Animal weight and rate of lambing among ewes were not used to stratify individuals to treatment because they were unknown at the time of assignment. The number of cows and ewes used each year varied based on stocking rate adjustments (Table 1). New animals needed when stocking rates were increased or replacements for culled individuals were similar to the existing livestock in age and breed composition. Cows and ewes that did not have progeny at the beginning of each grazing season were replaced with a contemporary with progeny. Lambing rates and initial weights of livestock varied among years (Table 1). All livestock resided on sagebrush (Artemisia spp. L.) dominated desert rangeland or farmland when not grazing the study site, as is typical for migration among seasonal grazing resources in this region.

\section{Data Collection}

All animals (cows, calves, ewes, and lambs) were individually weighed at initiation and termination of the grazing trial in mid-June and mid-September, respectively, of each year. Actual dates varied yearly based on range readiness for initiation and marketing of lambs for termination. Cattle and ewes remained on the study site for about 2 weeks after final weighing each year, but final weights had to be recorded before lambs were removed to be marketed. All animals were also weighed individually at midseason in all years when rotation

Table 1. Total number of cows and ewes assigned to treatments, mean number of lambs per ewe, and initial body weights of each class of livestock during each year.

\begin{tabular}{|c|c|c|c|c|c|c|c|}
\hline \multirow[b]{2}{*}{ Year } & \multirow[b]{2}{*}{ Cows } & \multirow[b]{2}{*}{ Ewes } & \multirow[b]{2}{*}{ Lamb rate } & \multicolumn{4}{|c|}{ Initial weight } \\
\hline & & & & Calves & Cows & Lambs & Ewes \\
\hline \multicolumn{4}{|c|}{$-\ldots---($ No. $)---$} & \multicolumn{4}{|c|}{ 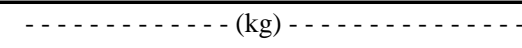 } \\
\hline 1980 & 127 & 669 & 1.66 & 133.0 & 409.9 & 22.6 & 64.0 \\
\hline 1981 & 144 & 738 & 1.67 & 123.4 & 407.4 & 18.9 & 61.1 \\
\hline 1982 & 153 & 793 & 1.54 & 126.1 & 417.6 & 18.8 & 61.9 \\
\hline 1983 & 161 & 801 & 1.55 & 126.1 & 415.9 & 22.0 & 60.5 \\
\hline 1984 & 172 & 867 & 1.60 & 126.0 & 487.0 & 18.6 & 62.5 \\
\hline 1985 & 177 & 880 & 1.54 & 128.4 & 477.9 & 22.8 & 67.0 \\
\hline 1986 & 171 & 943 & 1.56 & 164.6 & 510.0 & 20.8 & 63.9 \\
\hline 1987 & 168 & 838 & 1.61 & 148.4 & 491.2 & 25.3 & 70.7 \\
\hline 1988 & 172 & 905 & 1.59 & 141.1 & 505.0 & 25.4 & 67.9 \\
\hline 1990 & 120 & 646 & 1.53 & 118.4 & 538.6 & 25.6 & 67.1 \\
\hline
\end{tabular}

occurred in the deferred-rotation treatment. Data from 1989 are not used herein because reliable weight data were not collected that year. Weights were used to calculate average daily gain (ADG, $\mathrm{kg} \mathrm{day}^{-1}$ ) for each half and the entire grazing season for each class of livestock (calves, cows, lambs, ewes) and gain per ha $\left(\mathrm{kg} \mathrm{ha}^{-1}\right)$. Gain per ha was calculated over the entire season for progeny only, dams only, and total (progeny and dams combined). Production per ha of progeny only represents salable product to evaluate economically important productivity from each system, while production per ha of dams only and dams with progeny contributes to depiction of total biological productivity.

\section{Data Analysis}

Analysis of variance was conducted using a randomized-complete block design with a split-plot treatment structure. The $3 \times 2$ factorial of livetock species $X$ grazing method and their interaction was the main plot, using the combination of block $X$ species, block $X$ grazing method, plus block $X$ species $X$ grazing method as the error term. Year and its 2- and 3-way interactions with main plot effects were in the sub-plot, with the residual as the error term. This model was initially used to evaluate lambing rate and livestock weight at initiation of each grazing season because these were variables that could not be controlled for. Lambing rate did not respond to treatments or interactions $(\mathrm{P} \geq 0.55)$, but did vary among years $(\mathrm{P}=0.06)$. Lambing rate was not used as a covariate because this variation would be absorbed into the year effect. Initial weight varied $(\mathrm{P}=0.0001)$ among years for all classes of livestock, and sometimes varied among treatments $(\mathrm{P}<0.10)$. Therefore, initial weight was incorporated into the model as a covariate.

When $\mathrm{F}$ tests were significant within the main plot, least squares means were separated using LSD. Split-plot appropriate standard errors for least squares means and LSD for significant interactions were calculated according to Cochran and Cox (1957). When F tests were significant in the subplot, linear and quadratic contrasts were constructed to evaluate trends across years. Higher level polynomial contrasts could have been constructed, but were considered of little value in interpreting the data. Significance was interpreted at $\mathrm{P} \leq 0.05$ for all tests unless otherwise indicated.

\section{Results and Discussion}

Animal species and grazing method did not interact $(\mathrm{P}>0.05)$ for any dependent variable, so each of these main effects are discussed separately. Additionaly, year $X$ animal species $X$ grazing method was never significant (P>0.05).

\section{Livestock Performance}

Treatment Effects. Calf average daily gain $(\mathrm{ADG})$ was greater $(\mathrm{P}=0.03)$ over the entire grazing season when grazed alone rather than with sheep, although differences were small (Table 2). This difference was due primarily to higher $(\mathrm{P}=0.09)$ ADG during the first half of the grazing season followed by similar $(\mathrm{P}=0.49)$ ADG during the second half of the grazing season. This resulted in greater mid-season $(\mathrm{P}=0.05)$ and final $(\mathrm{P}=0.01)$ calf weights when grazed 
Table 2. Mean livestock average daily gain (ADG, $\mathrm{kg} \mathrm{day}^{-1}$ ) response in multispecies or deferredrotation grazing.

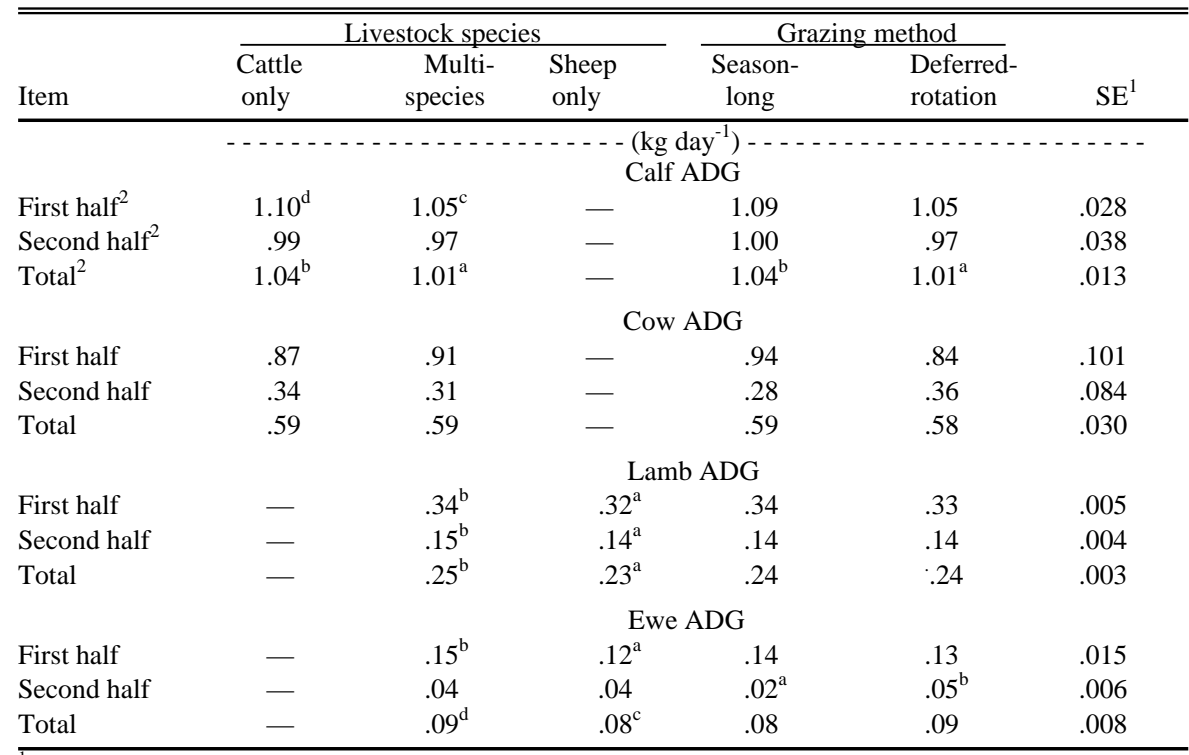

${ }^{1} \mathrm{SE}=$ Standard error.

${ }^{2}$ First half, second half, and total refer to portions of the grazing period.

${ }^{\mathrm{a}, \mathrm{b}}$ Within a row and ANOVA effect, means lacking a common superscript letter differ $(\mathrm{P}<0.05)$.

${ }^{\mathrm{c}, \mathrm{d}}$ Within a row and ANOVA effect, means lacking a common superscript letter differ $(\mathrm{P}<0.10)$

alone (Table 3). Cow ADG and weight (Tables 2 and 3 ) did not respond to species mixture $(\mathrm{P}>0.65)$. Lamb ADG (Table 2) was greater when mixed with cattle than alone during all periods $(\mathrm{P}=0.005,0.02$, and 0.001 for first half, second half, and total season, respectively). This resulted in lambs grazed with cattle being heavier at both midseason $(\mathrm{P}=0.003)$ and final $(\mathrm{P}=0.001)$ weigh dates (Table 3 ). Total season ewe ADG was greater $(\mathrm{P}=0.08)$ when mixed with cattle because the ewes with cattle gained more rapidly $(\mathrm{P}=0.04)$ during the first half of the season followed by similar $(\mathrm{P}=0.66)$ ADG during the second half (Table 2). Ewe weights were greater at both the mid-season $(\mathrm{P}=0.04)$ and final $(\mathrm{P}=0.04)$ weigh dates when mixed with cattle (Table 3 ). The difference in performance response by sheep and cattle may be because of historical sheep grazing on the study site that had shifted the plant community from forb to grass dominance, particularly Letterman's needlegrass (Bowns and Bagley 1986), that was avoided by sheep but relatively preferred by cattle. Thus, the decrease in sheep numbers relative to cattle resulted in decreased competition for less abundant forage desired by sheep. This allowed the sheep mixed with cattle to graze more selectively for their desired vegetation and, thus, despite its statistical significance. These results also agree with the literature, in that sheep performance usually increased when mixed with cattle, but cattle responses have been mixed, and usually smaller in magnitude than sheep responses (Nolan and Connolly 1997, Walker 1994, 1997). Walker (1994) also indicated that sheep appear to be more competitive than cattle when mixed because sheep are better able to select desired vegetation and can graze closer to the ground.

Grazing method did not influence calf average daily gain (ADG) (Table 2) during either half of the grazing season $(\mathrm{P}=$ 0.13 and 0.33 for first and second halves, respectively), but calves gained $0.03 \mathrm{~kg} \mathrm{day}^{-1}$ more $(\mathrm{P}=0.04)$ during the entire season under season-long than deferred-rotation grazing. This resulted in calves that weighed $2.3(\mathrm{P}=0.09)$ and $4.1 \mathrm{~kg}(\mathrm{P}=0.007)$ more at the midpoint and end of the grazing season, respectively (Table 3 ). This small difference does not appear to be biologically important, despite its statistical significance. Cow ADG and weight (Tables 2 and 3) did not respond to grazing method $(P>0.24)$. Lamb ADG did not respond $(\mathrm{P}>0.10)$ to grazing method during any period (Table 2). However, lamb mid-season weight (Table 3) was greater $(\mathrm{P}=0.07)$ under season-long grazing, but this difference disappeared $(\mathrm{P}=0.35)$ by market time (end of the grazing season). Ewe ADG (Table 2)

Table 3. Mean livestock weight $(\mathrm{kg})$ response to multispecies or deferred-rotation grazing at the middle and end of the grazing season.

\begin{tabular}{|c|c|c|c|c|c|c|}
\hline \multirow[b]{2}{*}{ Item } & \multicolumn{3}{|c|}{ Livestock species } & \multicolumn{2}{|c|}{ Grazing method } & \multirow[b]{2}{*}{$\mathrm{SE}^{1}$} \\
\hline & $\begin{array}{l}\text { Cattle } \\
\text { only }\end{array}$ & $\begin{array}{l}\text { Multi- } \\
\text { species }\end{array}$ & $\begin{array}{c}\text { Sheep } \\
\text { only }\end{array}$ & $\begin{array}{l}\text { Season- } \\
\text { long }\end{array}$ & $\begin{array}{r}\text { Deferred } \\
\text { rotation }\end{array}$ & \\
\hline & \multicolumn{6}{|c|}{$\begin{array}{c}\ldots \ldots \ldots \ldots \ldots \ldots \\
\text { Calf weight }\end{array}$} \\
\hline Middle & $186.5^{\mathrm{b}}$ & $183.8^{\mathrm{a}}$ & - & $186.3^{\mathrm{d}}$ & $184.0^{\mathrm{c}}$ & 1.2 \\
\hline \multirow[t]{2}{*}{ Final } & $235.8^{\mathrm{b}}$ & $232.5^{\mathrm{a}}$ & - & $236.2^{\mathrm{b}}$ & $232.1^{\mathrm{a}}$ & 0.8 \\
\hline & \multicolumn{6}{|c|}{ Cow weight } \\
\hline Middle & 505.9 & 506.4 & - & 508.8 & 503.5 & 4.6 \\
\hline \multirow[t]{2}{*}{ Final } & 523.5 & 523.0 & - & 524.2 & 522.2 & 3.2 \\
\hline & \multicolumn{6}{|c|}{ Lamb weight } \\
\hline Middle & - & $38.89^{b}$ & $37.44^{\mathrm{a}}$ & $38.41^{\mathrm{d}}$ & $37.92^{\mathrm{c}}$ & 0.2 \\
\hline \multirow[t]{2}{*}{ Final } & - & $45.51^{\mathrm{b}}$ & $43.37^{\mathrm{a}}$ & 44.48 & 44.29 & 0.2 \\
\hline & \multicolumn{6}{|c|}{ Ewe weight } \\
\hline Middle & - & $73.13^{\mathrm{b}}$ & $71.17^{\mathrm{a}}$ & 72.31 & 72.00 & 0.8 \\
\hline Final & - & $75.18^{\mathrm{b}}$ & $73.33^{\mathrm{a}}$ & 73.74 & 74.77 & 0.8 \\
\hline
\end{tabular}

${ }^{a, b}$ Within a row and ANOVA effect, means lacking a common superscript letter differ $(\mathrm{P}<0.05)$.

${ }^{\mathrm{c}, \mathrm{d}}$ Within a row and ANOVA effect, means lacking a common superscript letter differ $(\mathrm{P}<0.10)$.

receive a more nutritious diet, resulting dance of forage desired by cattle much greater, so ability to select a more difference in perfo a $0.03 \mathrm{~kg} \mathrm{day}^{-1}$ improvement in calf total-season ADG when grazed without sheep. This small difference does not appear to be biologically important,

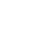


Table 4. Mean response of livestock average daily gain (ADG) and production per ha to year effect.

\begin{tabular}{|c|c|c|c|c|c|c|c|c|c|c|c|c|c|}
\hline \multirow[b]{2}{*}{ Item } & \multicolumn{10}{|c|}{ Year } & \multirow[b]{2}{*}{$\mathrm{SE}^{2}$} & \multicolumn{2}{|c|}{ Contrasts $^{1}$} \\
\hline & 1980 & 1981 & 1982 & 1983 & 1984 & 1985 & 1986 & 1987 & 1988 & 1990 & & $\overline{\mathrm{L}}$ & $\mathrm{Q}$ \\
\hline \multicolumn{14}{|c|}{ Calf ADG $\left(\mathrm{kg} \mathrm{day}^{-1}\right)$} \\
\hline First half $^{3}$ & .97 & .98 & 1.05 & 1.37 & .94 & 1.02 & .73 & 1.28 & 1.28 & 1.11 & .063 & .01 & .39 \\
\hline Total & .93 & .97 & .98 & 1.14 & .94 & 1.03 & .84 & 1.17 & 1.17 & 1.11 & .038 & .0001 & .22 \\
\hline \multicolumn{14}{|c|}{ Cow ADG $\left(\mathrm{kg} \mathrm{day}^{-1}\right)$} \\
\hline First half & .43 & .40 & .46 & 1.66 & .48 & .87 & 1.12 & 1.34 & 1.15 & .96 & .126 & .09 & .0003 \\
\hline \multicolumn{14}{|c|}{ Lamb ADG $\left(\mathrm{kg} \mathrm{day}^{-1}\right)$} \\
\hline First half & 657 & .282 & .305 & .275 & .268 & .297 & .322 & 288 & .330 & .279 & .008 & .0001 & .0001 \\
\hline Second half & 108 & .096 & .057 & .160 & .236 & .203 & .150 & .173 & .133 & .119 & .011 & .07 & .0001 \\
\hline Total & .261 & .211 & .228 & .231 & .254 & .251 & .232 & .238 & .239 & .220 & .006 & .60 & .36 \\
\hline \multicolumn{14}{|c|}{ Ewe ADG $\left(\mathrm{kg}\right.$ day $\left.^{-1}\right)$} \\
\hline First half & 109 & .107 & .118 & .131 & .100 & .141 & .156 & .173 & .199 & .119 & .013 & .003 & .24 \\
\hline Dams & 5.1 & 5.8 & 7.2 & 9.4 & 5.8 & 6.2 & 6.9 & 6.0 & 5.2 & 1.6 & .48 & .0001 & .0001 \\
\hline Total & 16.7 & 21.0 & 22.1 & 23.3 & 24.6 & 24.3 & 24.2 & 22.8 & 22.2 & 13.8 & .83 & .31 & .0001 \\
\hline
\end{tabular}

${ }^{\mathrm{T}}$ Probability of greater $\mathrm{F}$ for linear (L) and quadratic (Q) polynomial contrasts.

${ }^{2} \mathrm{SE}=$ Standard error

${ }^{3}$ First half, second half, and total refer to portions of the grazing period.

was similar $(\mathrm{P}=0.66)$ during the first half of the grazing season, but was over 2 times greater $(\mathrm{P}=0.008)$ under deferred-rotation grazing during the second half. Because ADG was much lower during the second than first half of the season, total-season ADG did not differ $(\mathrm{P}=0.18)$. Ewe weight (Table 3) did not differ at either date $(\mathrm{P}=0.63$ and 0.17 for mid- and final weights, respectively). However, this does not diminish the value of the difference in late-season ADG. Improving nutritional status as evinced by increasing body weight immediately before the breeding season can be important to fertility in ewes (Dunn and Moss 1992). Instituting deferred-rotation grazing in a mixedspecies system may benefit the sheep flock (ewe nutritional status at breeding) at the expense of the cattle herd (calf weaning weight). Depending on market conditions, this may be immaterial if both species are owned by the same producer, but could cause conflict if different producers own each species. Of 29 studies reviewed by Driscoll (1967), grazing methods such as deferred-rotation decreased (12), maintained (9), or increased (8) animal performance compared to continuous stocking. Pieper (1980) reviewed 24 studies, and reported that grazing method decreased (14), maintained (4), or increased (6) animal performance. Although there was some overlap of the studies in these 2 reviews, they indicate that grazing methods have no effect or are detrimental to livestock performance in the majority of cases. Many range scientists (Launchbaugh et al. 1978, Pieper 1980, Kothmann 1980, among others) have acknowledged that most specialized grazing methods have been developed to improve range vegetation characteristics with little concern for the effect on animals. Depending on the species of livestock chosen, this study provided mixed results, as well. The net effect, however, was that there was not a distinct advantage or disadvantage across both species of livestock.

Year Effects. Calf average daily gain $(\mathrm{ADG})$ increased linearly $(\mathrm{P} \leq 0.01)$ across years during all weigh periods (Table 4). This response may typify genetic improvement in the cow herd over time. However, interactions indicat-

Table 5. Mean livestock weight $\left(\mathrm{kg} \mathrm{ha}^{-1}\right)$ response by progeny, dams, and both to multispecies or deferred-rotation grazing.

\begin{tabular}{lccccccr}
\hline \hline & \multicolumn{3}{c}{ Livestock species } & & \multicolumn{2}{c}{ Grazing method } \\
\cline { 2 - 3 } Item & $\begin{array}{l}\text { Cattle } \\
\text { only }\end{array}$ & $\begin{array}{c}\text { Multi- } \\
\text { species }\end{array}$ & $\begin{array}{c}\text { Sheep } \\
\text { only }\end{array}$ & & $\begin{array}{c}\text { Season- } \\
\text { long }\end{array}$ & $\begin{array}{c}\text { Deferred } \\
\text { rotation }\end{array}$ & $\mathrm{SE}^{1}$ \\
\hline Progeny & $11.2^{\mathrm{a}}$ & $17.8^{\mathrm{b}}$ & $17.8^{\mathrm{b}}$ & & 16.3 & 14.8 & 1.42 \\
Dams & $6.4^{\mathrm{b}}$ & $6.7^{\mathrm{b}}$ & $4.7^{\mathrm{a}}$ & & 5.8 & 6.0 & .58 \\
Both & $17.6^{\mathrm{a}}$ & $24.5^{\mathrm{b}}$ & $22.4^{\mathrm{b}}$ & & 22.1 & 20.9 & 1.89 \\
\hline
\end{tabular}

${ }^{1} \mathrm{SE}=$ Standard error

${ }^{\mathrm{a}, \mathrm{b}}$ Within a row and ANOVA effect, means lacking a common superscript letter differ $(\mathrm{P}<0.05)$. ed it was modified by treatments. Grazing method interacted with year for ADG during the second half of the season $(\mathrm{P}=0.01$, Fig. 2$)$. There was no trend across years under season-long grazing but a linear increase $(\mathrm{P}=0.0005)$ in $\mathrm{ADG}$ under deferred-rotation grazing. Apparently, calves performed more poorly under deferred-rotation in the early years but improved to be comparable to season-long grazing during the remainder of the study. Species $(\mathrm{P}=0.01)$ and grazing method $(\mathrm{P}=0.04)$ both interacted with year for total season ADG (Fig. 2). Calf ADG increased linearly both with and without sheep, but also tended to change quadratically without sheep. Average daily gain responded quadratically under season-long but linearly under deferred-rotation grazing. Differences in responses depicted by these interactions are relatively small 


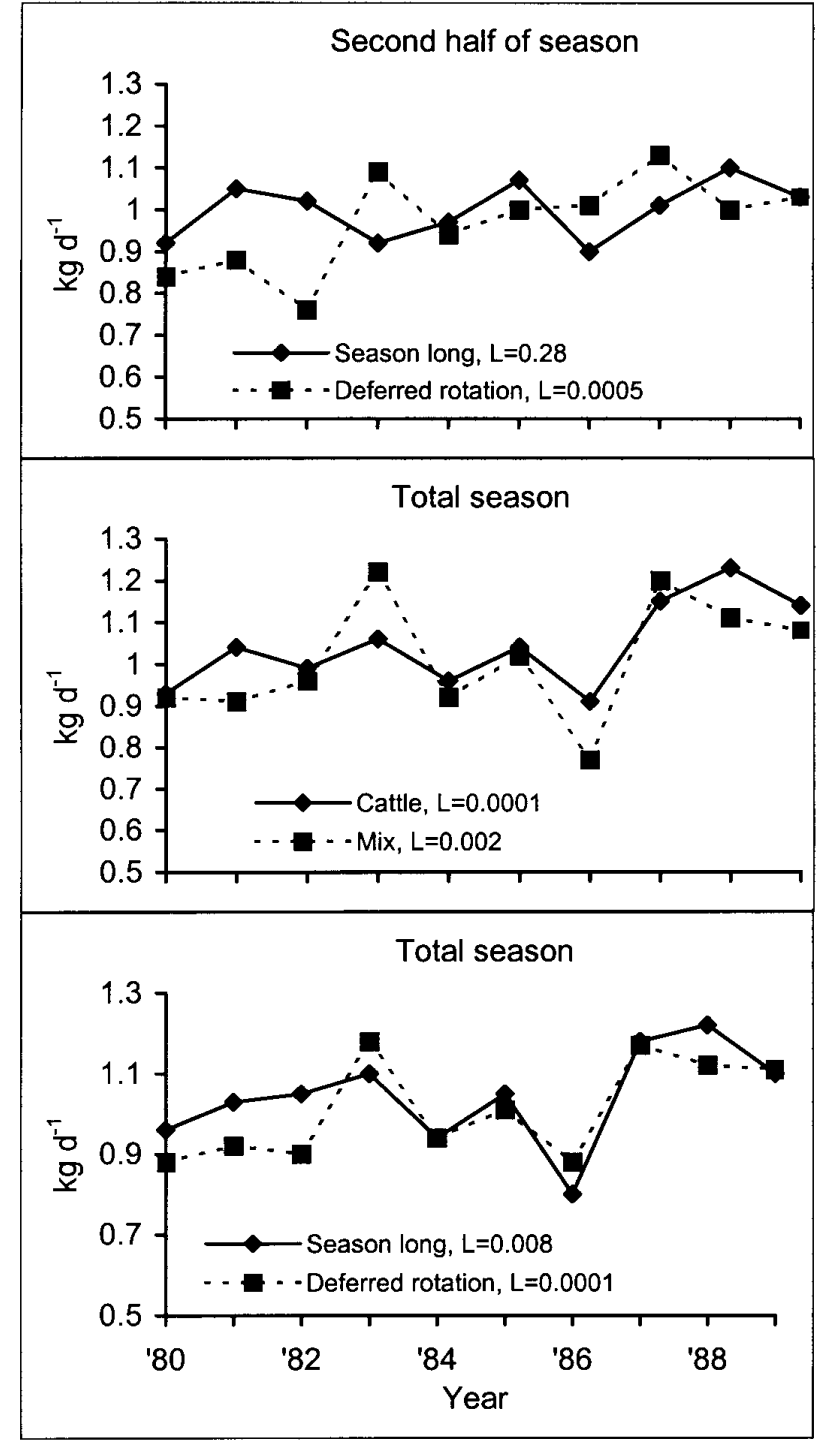

Fig. 2. Mean calf average daily gain $\left(\mathrm{kg} \mathrm{day}^{-1}\right)$ response to significant year $\times$ livestock species and year $\times$ grazing method interactions. Standard error $=\mathbf{0 . 1 1}$ for years within and across treatments for second half of season responses, and 0.08 for years within treatments and 0.07 for years across treatments for total season responses. In the legends, $L$ refers to the probability of greater $\mathbf{F}$ for linear polynomial contrasts.

and appear biologically unimportant despite statistical significnace.

Cow ADG varied $(\mathrm{P} \leq 0.0003)$ quadratically across years for all weigh periods (Table 4). Species $(\mathrm{P} \leq 0.05)$ and grazing method $(\mathrm{P} \leq 0.02)$ interacted with year for total season ADG (Fig 3). All treatments displayed quadratic responses in these interactions. Even though trends were similar, interactions occurred because relative ranking of treatment means varied among years. As with calf $\mathrm{ADG}$, these interactions result from small differences that appear biologically unimportant, despite statistical signifi-

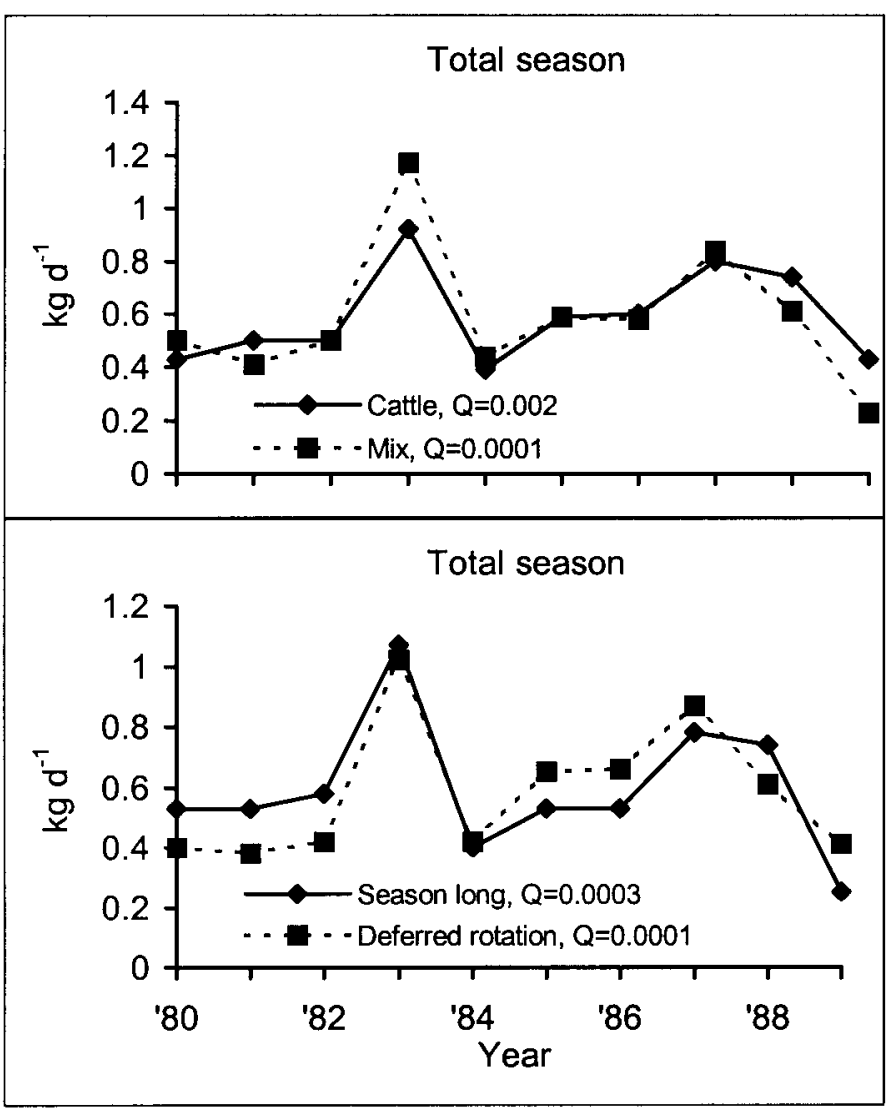

Fig. 3. Mean cow average daily gain $\left(\mathrm{kg} \mathrm{day}^{-1}\right)$ response to significant year $X$ livestock species and year $\times$ grazing method interactions. Standard error $=0.11$ for years within and across treatments. In the legends, $Q$ refers to the probability of greater $F$ for quadratic polynomial contrasts.

cance. The quadratic responses appear to be similar to the annual precipitation pattern suggesting that nutritional status of mature cows varied with forage conditions, as opposed to the linear increase in ADG over time observed with growing calves. Cow ADG was particularly high in the recordsetting wet year of 1983 and particuarly low in 1990, which was the second consecutive year of severe drought.

Lamb average daily gain (ADG) also varied $(\mathrm{P}=0.0001)$ among years for all periods (Table 4). First- and second-half ADG changed quadratically $(P=$ 0.0001 ) across years, but in opposite directions. Thus, total season ADG did not display linear or quadratic responses. Grazing method interacted with year for all periods ( $\mathrm{P} \leq 0.03$, Fig. 4). Both grazing methods displayed the same polynomial contrasts across years as the corresponding year main effects, again indicating that the interaction effect was relatively unimportant. Lamb performance did not show the same linear increase as calf performance.

Ewe ADG varied $(\mathrm{P} \leq 0.001)$ among years for all periods (Table 4). Ewe ADG increased linearly $(\mathrm{P}=0.003)$ across years during the first half and responded quadratically $(\mathrm{P}=0.0001)$ during the second half and total grazing season. Grazing method interacted with year for first $(\mathrm{P}=0.0005)$ and second half $(\mathrm{P}=0.0001)$ ADG (Fig. 5). Livestock species also interacted with year $(\mathrm{P}=0.04)$ for second half ADG (Fig. 5). As with lambs, both species and grazing method treatments displayed similar polynomial contrasts across years as the year main effects. Ewe performance also appeared to respond to precipitation conditions, but differences among wet and dry years were not as severe as with cows. 


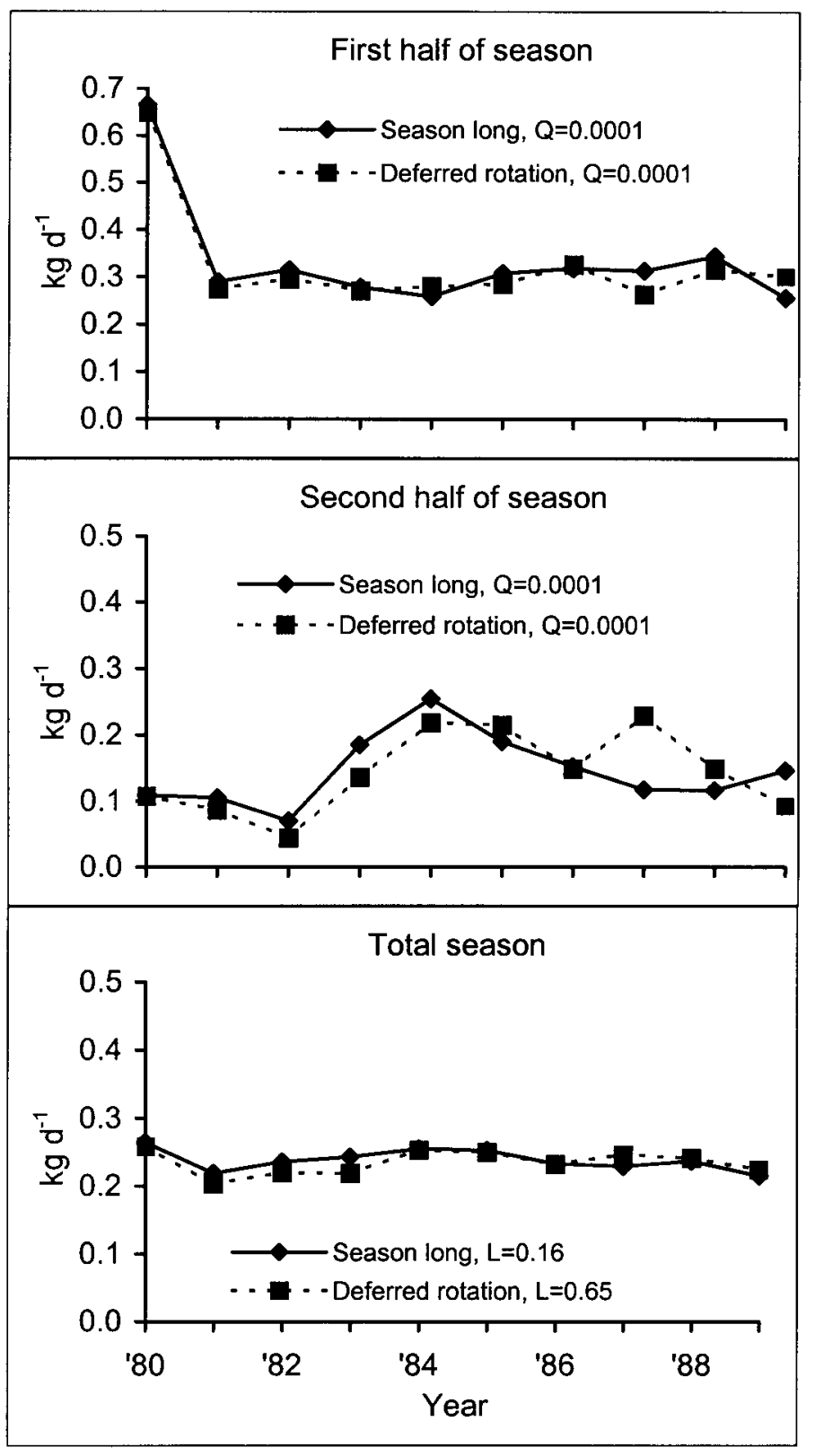

Fig. 4. Mean lamb average daily gain $\left(\mathrm{kg} \mathrm{day}^{-1}\right)$ response to significant year $\times$ grazing method interactions. Standard error $=\mathbf{0 . 0 1 6}$ for years within and across treatments for first half of season responses, 0.021 for years within treatments and 0.020 for years across treatments for second half of season responses, and 0.011 for years within and across treatments for total season responses. In the legends, $L$ and $Q$ refer to the probabilities of greater $\mathbf{F}$ for linear and quadratic polynomial contrasts, respectively.

\section{Production per unit land}

Mixed species grazing affected gain per ha (Table 5) of progeny $(\mathrm{P}=0.002)$, dams $(\mathrm{P}=0.008)$, and combined progeny and dams $(\mathrm{P}=0.009)$. Production of progeny only and both progeny and dams was similar between mixed species and sheep alone, but less with cattle alone. Production by dams was similar between cattle only and mixed are marketed annually if a beef or sheep producer practices a typical reproductive female replacement rate of $20 \%$. Because of their larger size, the proportion of gross income from sale of cull dams often exceeds the proportion of the herd culled. Thus, use of mixed species or sheep grazing should promote the greatest economic return to investment in land. In addition, the evaluation of biological productivity per unit land should include both progeny and dams. The 2 livestock species displayed opposite relative rankings in terms of progeny or dam level of production. This appears to be a function of partitioning of nutrient intake by dams into lactation products (progeny growth) vs body energy reserves. Sheep appear to partition a greater portion of nutrition into lamb growth (Matthews et al. 1986). When considering total production by both age groups combined, the greater productivity by cows was masked by progeny production from sheep because the overall level of growth from progeny was much greater than from dams (Tables 2 and 5).

Production per ha varied quadratically among years $(\mathrm{P}=0.0001)$ for all 3 age groups (Table 4). Additionally, species interacted with year $(\mathrm{P}=0.0001)$ for all 3 age groups (Fig. 6). However, species treatments displayed similar quadratic relationships as corresponding year main effects. This temporal response appeared to follow the precipitation pattern in a similar manner to the majority of animal performance responses.

\section{Conclusions and Implications}

Many of the differences among treatments that were statistically significant were so small that they were probably biologically and economically unimportant. However, differences among years, primarily because of weather conditions, were large. For example, production by progeny $\left(\mathrm{kg} \mathrm{ha}^{-1}\right)$ was $60 \%$ greater in the best year than the poorest year. This pattern of weather conditions overwhelming treatment responses is common in long-term grazing trials. Keeping the small magnitude of treatment differences in mind, the following conclusions can be drawn about the value of implementing the management practices evaluated herein. 


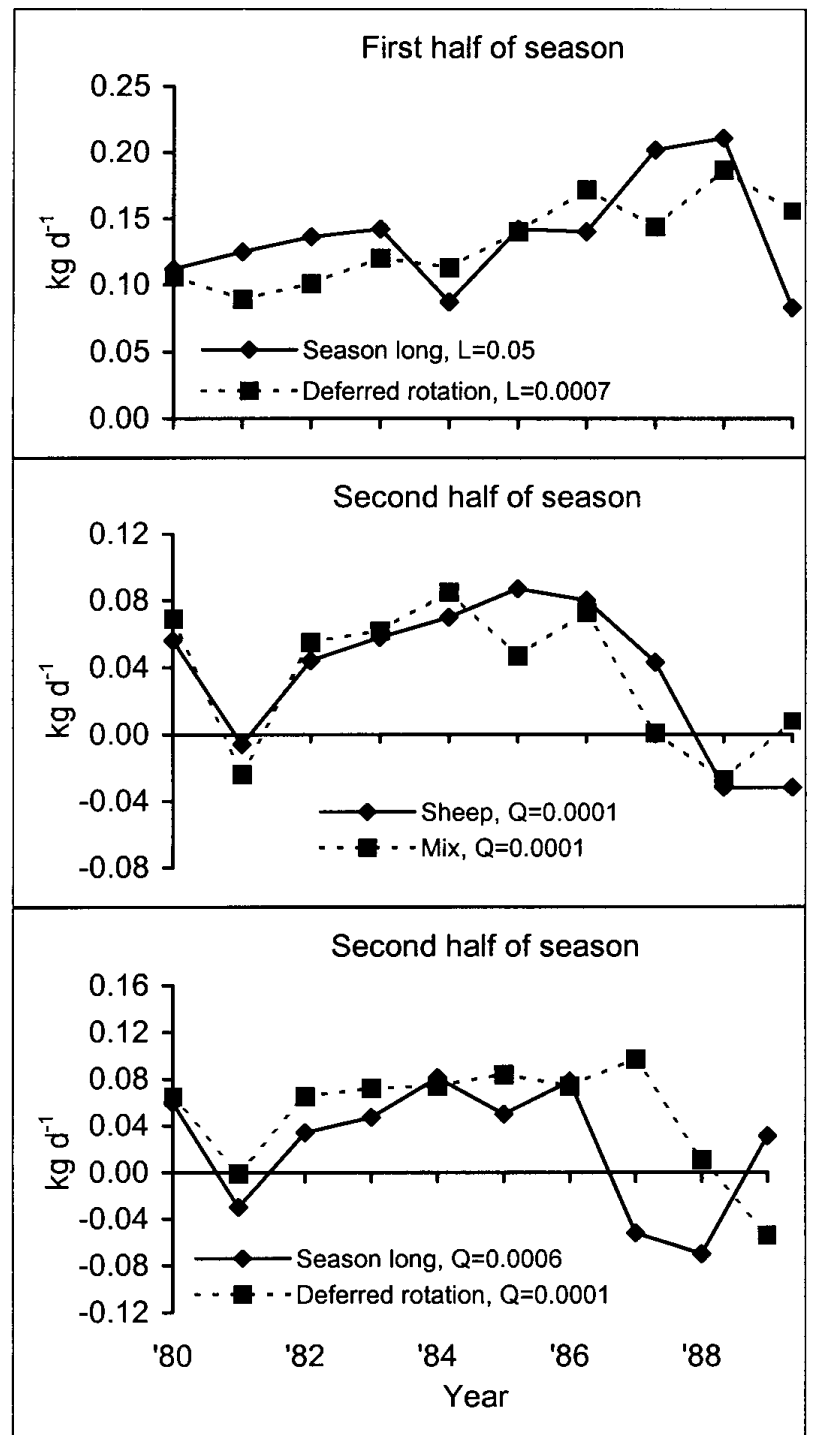

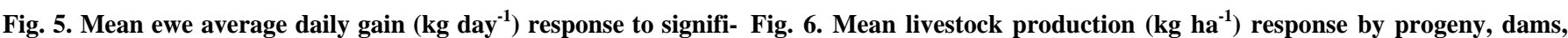
cant year $\times$ livestock species and year $\times$ grazing method interactions. Standard error $=\mathbf{0 . 0 2 6}$ for years within treatments and 0.029 for years across treatments for first half of season responses, and 0.024 for years within treatments and 0.023 for years across treatments for second half of season responses. In the legends, $L$ and $Q$ refer to the probabilities of greater $F$ for linear and quadratic polynomial contrasts, respectively.

Conversion of this rangeland type from historical sheep grazing to mixed species grazing provides a small improvement in rate of weight gain by lambs and ewes. This would yield similar production per unit land of marketable product (progeny), but increased production per ha by dams. Converting from single to mixed species grazing could have other potential benefits, including reduced economic risk by diversification of enterprises and improved cash flow by marketing of multiple products (Walker 1994), reduced loss of sheep to predators

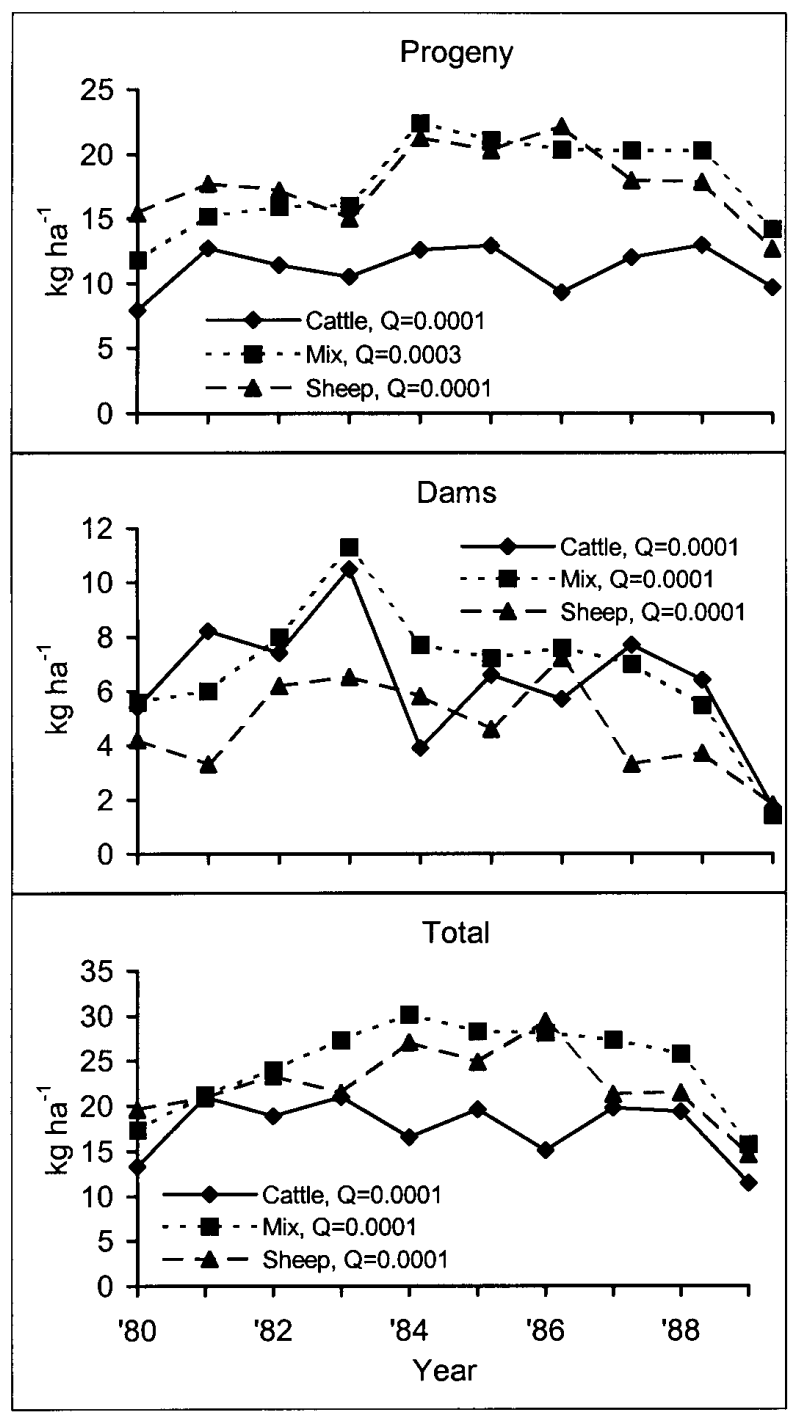

and total (progeny and dams combined) to year $\times$ livestock species interactions. Standard error for progeny $=1.3$ for years within species and 1.9 for years across species, 1.2 for years within species and 1.3 for years across species for dams, and 2.1 for years within species and 2.7 for years across species for total. In the legends, $Q$ refers to the probability of greater $\mathbf{F}$ for quadratic polynomial contrasts. because of cow presence, and reduced parasite loads (Baker and Byington 1986). However, total conversion from sheep to cattle does not appear advisable on this vegetation type. While cows and calves performed similarly or slightly better when alone, production per unit land was reduced with cattle only compared to sheep only or mixed species grazing. Additionally, tall larkspur is common in this vegetation type, posing potential toxicity concerns for cattle. However, because sheep are more resistant to larkspur poisoning, their grazing of larkspur under mixed species grazing may decrease cattle poisoning.

Conversion from historical, continuous grazing to deferred-rotation grazing appeared appropriate for a sheep only or mixed species enterprise, primarily because of the improvement in ewe nutritional status shortly before breeding. This appeared to offset reduced calf ADG under deferred-rotation grazing using mixed species. However, if this resource was converted to a cattle enterprise, continuous grazing would be superior because it allowed greater calf performance. 


\section{Literature Cited}

Abaye, A.O., V.G. Allen, and J.P. Fontenot. 1994. Influence of grazing cattle and sheep together and separately on animal performance and forage quality. J. Anim. Sci. 72:1013-1022.

Baker, F.H. and E.K. Byington. 1986. Enhancing production of ruminant species through multispecies grazing systems. Prof. Anim. Sci. 2:9-14.

Bennett, D., F.H.W. Morley, K.W. Clark, and M.L. Dudzinski. 1970. The effect of grazing cattle and sheep together. Australian J. Exp. Agr. Anim. Husb. 10:694-709.

Bowns, J.E. and C.F. Bagley. 1986. Vegetation responses to long-term sheep grazing on mountain ranges. J. Range Manage. 39:431-434.

Cochran, W.G. and G.M. Cox. 1957. Experimental designs. Wiley and Sons, New York.

Driscoll, R.S. 1967. Managing public rangeland: Effective livestock grazing practices and systems for national forests and national grasslands. USDA AIB 315 . Washington, D.C.
Dunn, T.G. and G.E. Moss. 1992. Effects of nutrient deficiencies and excesses on reproductive efficiency of livestock. J. Anim. Sci. 70:1580-1593.

Kothmann, M.M. 1980. Integrating livestock needs to the grazing system, p. 65-83. In: K.C. McDaniel and C. Allison (eds.), Proc. Grazing Management Systems for Southwest Rangelands Symp. Range Improvement Task Force. New Mexico State Univ., Las Cruces, N.M.

Launchbaugh, J.L., C.E. Owensby, F.L. Schwartz, and L.R. Corah. 1978. Grazing management to meet nutritional and functional needs of livestock, p. 541-546. In: D.N. Hyder (ed.), Proc. 1st Int. Rangeland Congr. Soc. Range Manage. Denver, Colo.

Matthews, D.H., W.C. Foote, R.L. Hurst, and J.E. Bowns. 1986. Response of cattle and sheep under various grazing systems on high elevation summer ranges. Prof. Anim. Sci. 2:18-23.

Merrill, L.B. and V.A. Young. 1954. Results of grazing single classes of livestock in combination with several classes when stocking rates are constant. Texas Agr. Exp. Sta. Prog. Rep. 1726. Texas A\&M Univ., College Station, Tex.
Merrill, L.B., P.O. Reardon, and C.L. Leinweber. 1966. Cattle, sheep, and goats-mix'em up for higher gains. Texas Agr. Prog. 12:(4):13-14.

Nolan, T. and J. Connolly. 1977. Mixed stocking by sheep and steers-a review. Herb. Abstr. 47:367-374.

Nolan, T. and J. Connolly. 1989. Mixed v. mono-grazing by steers and sheep. Anim. Prod. 48:519-533.

Pieper, R.D. 1980. Impacts of grazing systems on livestock, p. 133-151. In: K.C. McDaniel and C. Allison (eds), Proc. Grazing Management Systems for Southwest Rangelands Symp. Range Improvement Task Force. New Mexico State Univ. Las Cruces, N.M.

Taylor, C.A. 1985. Multispecies grazing research overview (Texas), p. 65-83. In: F.H. Baker and R.K. Jones (Eds.), Proc. Conf. on Multispecies Grazing. Winrock Int. Morrilton, Ark.

Walker, J.W. 1994. Multispecies grazing: the ecological advantage. Sheep Res. J. Special Issue: 52-64.

Walker, J.W. 1997. Multispecies grazing: the ecological advantage. Proc., West. Sec. Amer. Soc. Anim. Sci. 48:7-10. 